\title{
Identification and phenotypic plasticity of Pseudanabaena catenata from the Svalbard archipelago
}

\author{
Zoya KHAN ${ }^{1}$, Wan Maznah WAN OMAR ${ }^{*}$, Faradina Merican Mohd Sidik MERICAN ${ }^{1}$, \\ Asmimie Asmawarnie AZIZAN¹, Choon Pin FOONG ${ }^{1}$, Peter CONVEY², \\ Nazalan NAJIMUDIN 1 , Jerzy SMYKLA ${ }^{3}$ and Siti Aisyah ALIAS ${ }^{4}$ \\ ${ }^{1}$ School of Biological Sciences, Universiti Sains Malaysia, 11800 Penang, Malaysia \\ ${ }^{2}$ British Antarctic Survey, NERC, Cambridge CB3 OET, United Kingdom \\ ${ }^{3}$ Department of Biodiversity, Institute of Nature Conservation, Polish Academy of Sciences, \\ Mickiewicza 33, 31-120 Krakow, Poland \\ ${ }^{4}$ Institute of Ocean and Earth Sciences, University Malaya, 50603 Kuala Lumpur, Malaysia \\ *corresponding author<wmaznah@usm.my>
}

\begin{abstract}
A filamentous benthic cyanobacteria, strain USMAC16, was isolated from the High Arctic Svalbard archipelago, Norway, and a combination of morphological, ultrastructural and molecular characterisation (16S rRNA gene sequence) used to identify to species level. Cell dimensions, thylakoid arrangement and apical cell shape are consistent with the Pseudanabaena genus description. The molecular characterisation of $P$. catenata gave 100\% similarity with Pseudanabaena catenata SAG 1464-1, originally reported from Germany. Strain USMAC16 was cultured under a range of temperature and photoperiod conditions, in solid and liquid media, and harvested at exponential phase to examine its phenotypic plasticity. Under different culture conditions, we observed considerable variations in cell dimensions. The longest cell $(5.91 \pm 0.13 \mu \mathrm{m})$ was observed at $15^{\circ} \mathrm{C}$ under 12:12 light:dark, and the widest cell $(3.24 \pm 0.06 \mu \mathrm{m})$ at $4^{\circ} \mathrm{C}$ under $12: 12$ light: dark in liquid media. The study provides baseline data documenting the morphological variation of $P$. catenata in response to changing temperature regimes.
\end{abstract}

Key words: Arctic, cyanobacteria, Pseudanabaena, polyphasic approach, 16S rRNA.

\section{Introduction}

The cyanobacterial genus Pseudanabaena (Lauterborn 1915) has undergone several taxonomic and systematic revisions. In traditional classification systems, the genus was placed in the family Oscillatoriaceae and contained only two species, namely, P. catenata and P. constricta (Szafer 1910) under (Geitler 1932). However, in the more recent cyanobacteria classification system 
proposed by Anagnostidis and Komárek (1988), the genus Pseudanabaena is classified under the class Cyanophyceae, sub-class Synechococcophycideae, order Synechococcales, family Pseudanabaenaceae (Komárek et al. 2014), and comprises more than 33 species. The current taxonomic state of Pseudanabaena remains unsatisfactory due to the accumulation of DNA sequences in GenBank and the description of new species (Komárek and Anagnostidi 2005; Kling and Watson 2003). Furthermore, some cyanobacteria can show high morphological variability under different growth conditions (Lyra et al. 2001; Nalewajko and Murphy 2001; Gugger et al. 2002; Gupta and Agrawal 2006), making identification of species based on morphology alone unreliable.

Cyanobacterial classification has undergone further development in recent years (Komárek et al. 2014). It has been estimated that as many as $50 \%$ of cyanobacterial strains listed in public databases have been identified incorrectly (Komárek and Anagnostidis 1989). The application of modern molecular analytical approaches, including the sequencing of $16 \mathrm{~S}$ rRNA genes and the 16S-23S internal transcribed region (ITS), and of Electron Microscopy (EM) and new biochemical and molecular methods have driven considerable improvement in the characterisation of cyanobacteria (Rippka et al. 1979; Komárek and Anagnostidis 1986, 2005; Castenholz 2001; Komárek 2003). Komárek (2006), however, also notes that the names of misidentified strains are rarely updated or corrected in databases (such as GenBank) and collection lists, and the lack of complete information on morphology leads to incorrect allocation of species names to GenBank strains. To overcome this problem, Komárek and Anagnostidis (2005) aimed to erect phylogenetically robust taxa based on morphology.

Although the genus Pseudanabaena is widely distributed, the phenotypic and genetic diversification of these filamentous cyanobacteria remain poorly known (Acinas et al. 2009). Taxonomic information, such as ultrastructure features, pigment composition, DNA sequence data, and confirmation of interspecific phylogenetic relationships for most Pseudanabaena species, remains incomplete (Yu et al.2015). Taking advantage of the rapid current developments in molecular and systematic approaches, the purpose of this study was twofold. First, a strain of Pseudanabaena isolated from the High Arctic Svalbard archipelago was subjected to a detailed polyphasic characterisation using a combination of electron microscopy together with $16 \mathrm{~S}$ rRNA and 16S-23S internal transcribed spacer (ITS) sequencing. Second, the morphological plasticity of this strain was documented under various temperature and light (daylength) regimes in order to confirm the morphological features that are reported to be stable and are of highest taxonomic importance. 


\section{Materials and methods}

Sample collection and isolation. - Soil sediments were collected from small

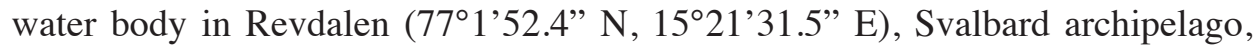
Norway. A single isolate was obtained by streaking and serial dilution methods (Andersen 2005). Cultures were grown in BG-11 liquid media (Rippka et al. 1979) and incubated at a temperature of $15 \pm 2^{\circ} \mathrm{C}$, a photoperiod of $12 \mathrm{~L}: 12 \mathrm{D}$, and a daytime light intensity of $27 \mu \mathrm{mol} \mathrm{m} \mathrm{m}^{-2} \mathrm{~s}^{-1}$. Cycloheximide $(50 \mathrm{mg} / \mathrm{L})$ was added to liquid and agar media to remove green algae contamination.

Morphological identification and phenotypic plasticity. - Light microscopy was performed using an Olympus microscope (Model BX53F, Olympus, Japan) equipped with camera (Olympus, Japan). The individual cells were observed at 1000x magnification. Thirty mature trichomes were observed and cell length and cell width of the apical cell from each trichome were measured using cell measurement software (Cell Sens Standard Version 1.4.1).

Crossed gradients (Kvíderová and Lukavský 2001) were used to test the effect of various temperature and light conditions on the morphology and growth of this strain, using liquid and solid media. For liquid treatment, $100 \mathrm{ml}$ of BG-11 was added to $250 \mathrm{ml}$ Erlenmeyer flasks, and $10 \mathrm{ml}$ of the cyanobacteria culture was inoculated into the flasks. For solid media, cyanobacteria were streaked onto BG-11 agar media plates.

In order to examine morphological responses to changing environmental conditions, the strain was exposed to nine different combinations of temperature and light duration using the cross gradient approach (Fig. 1) for 10 days. The temperature ranged from $4^{\circ} \mathrm{C}$ to $25^{\circ} \mathrm{C}$, and the range of light exposure duration was 12 to $24 \mathrm{~h}$. Observations were made using an Olympus BX53F microscope at 1000x magnification, and the length and width of the apical cell from 30 mature trichomes were again measured. Growth rates were measured in liquid media by the cell count method using a haemocytometer. Cell counting was carried out under a light microscope daily for 10 days.

Statistical analysis of morphological data. - The mean values of growth rates and measured morphological parameters were compared using a $3 \times 3$ factorial design with a two-way analysis of variance (ANOVA) in SPSS (Statistical Package for the Social Sciences) v20.0 software, with temperature and light duration as the fixed factor. We tested pairwise differences using a Duncan post hoc test $(P<0.05)$. All data are presented as mean \pm standard error.

TEM (Transmission Electron Microscopy). - For TEM, samples were harvested from growing cultures and fixed using Mc Dowell-Trump fixative prepared in $0.1 \mathrm{M}$ phosphate buffer $(\mathrm{pH}$ 7.2). The samples were treated with 


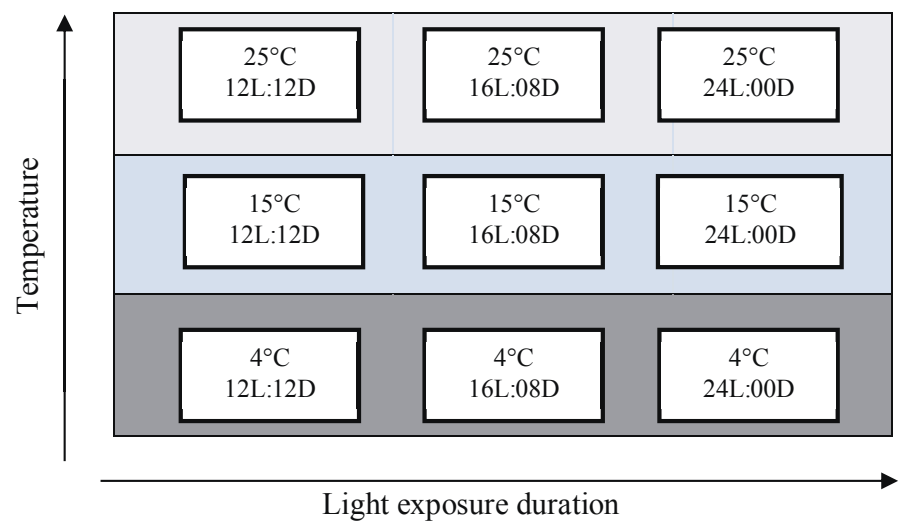

Fig. 1. Experimental design for estimation of morphological variability of Pseudanabaena catenata in relation to temperature and light exposure duration. L and D indicates light and dark hours, respectively.

buffer wash twice and post-fixed with osmium tetraoxide. Dehydration of samples was carried out using an alcohol gradient series. Samples were embedded in Spurr's resin and sectioned at $<0.1 \mu \mathrm{m}$ using an ultramicrotome (PowerTome XL, USA). Sectioned samples were stained with uranyl acetate and lead citrate before viewing under TEM (EFTEM Libra 120 equipped with Olympus, SIS iTem version 5.0, Germany).

DNA isolation. - Total DNA was extracted from cells harvested at exponential phase using the Wizard genomic DNA purification kit (Promega, USA). The presence of DNA in the extracts was confirmed by $1 \%$ agarose gel electrophoresis and quantified using a Nanodrop spectrophotometer (Thermo Fisher Scientific, USA).

Molecular characterisation. - The DNA was used as a template for PCR amplification of the 16S rDNA gene and 16S-23S ITS region with cyanobacteriaspecific primers (Boyer et al. 2001) (Table 1). For PCR, $10 \mathrm{ng}$ of extracted DNA was used in each $20 \mu \mathrm{L}$ reaction mixture, which consisted of $1 \mu \mathrm{l}$ of each forward and reverse primer, $2 \mu \mathrm{L}$ of $\mathrm{MgCl}_{2}$ buffer, $2 \mu \mathrm{L}$ dNTP mixture and 0.5 units Ex Taq DNA polymerase (all from intron iTaq plus). DNA extracted from cultured strains of Pseudanabaena catenata was the positive control while the negative control had no DNA template. PCR was conducted in a Bio-Rad Thermal Cycler with the following parameters: $94^{\circ} \mathrm{C}$ for $1 \mathrm{~min}, 56^{\circ} \mathrm{C}$ for $1 \mathrm{~min}$, $72^{\circ} \mathrm{C}$ for $4 \mathrm{~min}$ ( 35 cycles), followed by $10 \mathrm{~min}$ extension at $72^{\circ} \mathrm{C}$. The products were confirmed on $1 \%$ agarose gels before sending for commercial sequencing 
Table 1

List of primers used in this study.

\begin{tabular}{|c|c|c|c|}
\hline Primer name & Primer sequence 5'-3' & Target & Reference \\
\hline Primer 2 & 5'GGGGGATTTTCCGCAATGGG3' & 16S rRNA & Boyer et al., 2001 \\
\hline Primer 3 & 5'CGCTCTACCAACTGAGCTA 3' & 16S rRNA & Boyer et al., 2001 \\
\hline Primer 1 & 5'CTCTGTGTGCCTAGGTATCC 3' & ITS & Boyer et al., 2001 \\
\hline Primer 5 & 5'TGTAGCTCAGGTGGTTAG 3' & ITS & Boyer et al., 2001 \\
\hline
\end{tabular}

(Sanger sequencing, MyTACG Bioscience Enterprise, Malaysia). Matrix standard was prepared by using the BigDye Terminator kit and electropherograms were checked using an ABI 3730 sequencer (ThermoFisher, USA).

The 16S rRNA sequence (1029 bp) and 16S-23S ITS region (654 bp) of the isolated strain were analysed by using the BLAST nucleotide search function of GenBank and the Seq Match tool of the Ribosomal Database Project II (http:// www.ncbi.nlm.nih.gov/ and http://rdp.cme.msu.edu/, respectively). Pseudanabaena catenata strain USMAC16 16S rRNA and ITS sequences were deposited in the GenBank database under accession number KT318760 and KX668261, respectively.

Phylogenetic analysis was conducted by using two sets of sequence data (16S rRNA gene and 16S-23S ITS). Each set comprised 10 strains of Pseudanabaena listed in GenBank. The homologous sequences were identified using a MegaBlast search of the NCBI database. These sequences were aligned using the CLUSTAL W program (http://www.ebi.ac.uk/). Phylogenetic analysis was carried out in Mr. Bayes version 3.2 (Ronquist and Huelsenbeck 2003) and MEGA version 6 (Tamura et al. 2013). Bayesian Inference was implemented in Mr. Bayes. The evolutionary model used was the K2+gamma model, selected on the basis of the BIC (Bayesian Information Criterion) model using modeltest in MEGA (version 6; Tamura et al. 2013). Bayesian analysis was performed with parameters set to 2 replicates of 8 chains each for 1,000,000 generations, and trees at every 100 generations were sampled. The first 1000 trees were discarded as burn-in. Parameter 220 stability was estimated by plotting log-likelihood values against generation time, and a consensus tree with posterior probabilities was then generated. Maximum-likelihood (ML) analysis was implemented in MEGA version 6 (Tamura et al. 2013) under Kimura's two-parameter (K2P), and bootstrap re-sampling was performed using 1000 replications. 
Results and discussion

\section{Morphology and phenotypic plasticity under various conditions}

Description. - In liquid media, the isolate grew as dark blue-green filaments suspended in the medium, older cultures formed a thin layer on the walls and bottom of the culture vessel. On solid media, the filaments aggregated into colonies and did not show any colonial gliding motility or phototaxis even after a long duration of light exposure.

Trichomes are straight, short and motile without oscillation and rotation, and distinctly constricted at cross-walls (Fig. 2). Cells pale blue-green, isodiametric or up to $2 \times$ longer than wide, $1.2-2.2 \mu \mathrm{m}$ in width and $2-5 \mu \mathrm{m}$ in length, cell content differentiated into centroplasm and chromatoplasm. apical cells round without polar aerotopes and calyptras, no terminal attenuation, heterocytes and akinetes absent. Reproduction is by one or two celled hormogonia.

Occurrence. - Pseudanabaena catenata is distributed worldwide and very common in fresh water. It is benthic and can be found in muddy sediments of lakes and other water bodies (Lauterborn 1915). The presence of Pseuadanabaena sp., along with, Leptolyngbya cf. notate ((Schmidle) Anagnostidis and Komárek 1988), Leptolyngbya tenuis ((Gomont) Anagnostidis and Komárek 1988), Pseudophormidium sp. ((Forti) Anagnostidis and Komárek 1988), Phormidium sp. (Kützing ex Gomont 1892), Nostoc sp. (Vaucher ex Bornet and Flahault 1886) has previously been reported in the Svalbard archipelago (Kaštovská et al. 2005).

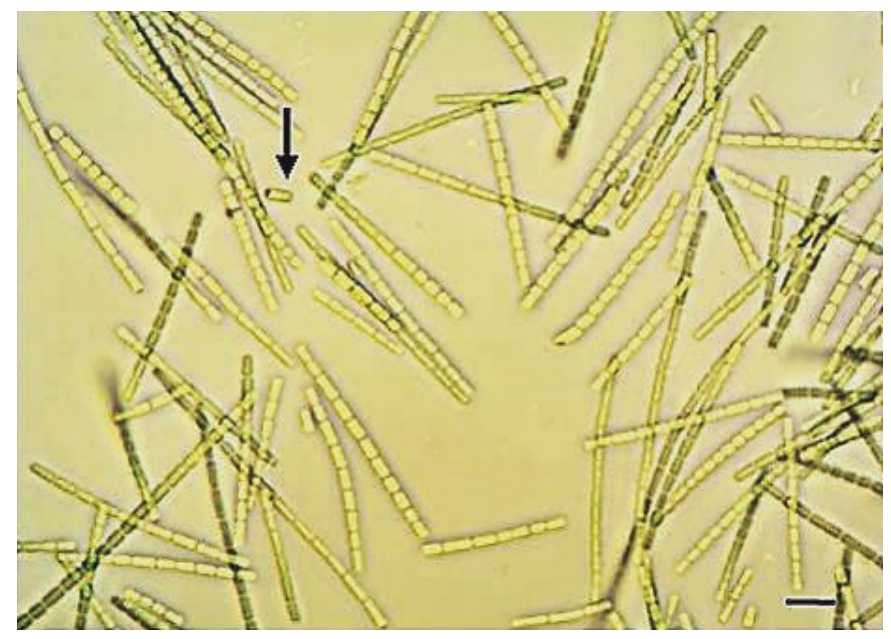

Fig. 2. Light micrograph of Pseudanabaena catenata colony with one celled hormogonia (arrow). Scale bar $5 \mu \mathrm{m}$. 
Growth rates of $P$. catenata was evaluated at various temperatures and daylength durations over a period of 10 days (Fig. 3). The highest cell growth rate achieved $\left(1.62 \pm 0.13\right.$ cell $/ \mathrm{ml} /$ day or day $\left.^{-1}\right)$ was measured at $15^{\circ} \mathrm{C}$ and $12 \mathrm{~L}: 12 \mathrm{D}$, and the lowest cell growth rates $\left(0.82 \pm 0.04\right.$ day $\left.^{-1}\right)$ at $25^{\circ} \mathrm{C}$, and $24 \mathrm{~L}: 00 \mathrm{D}$. The post
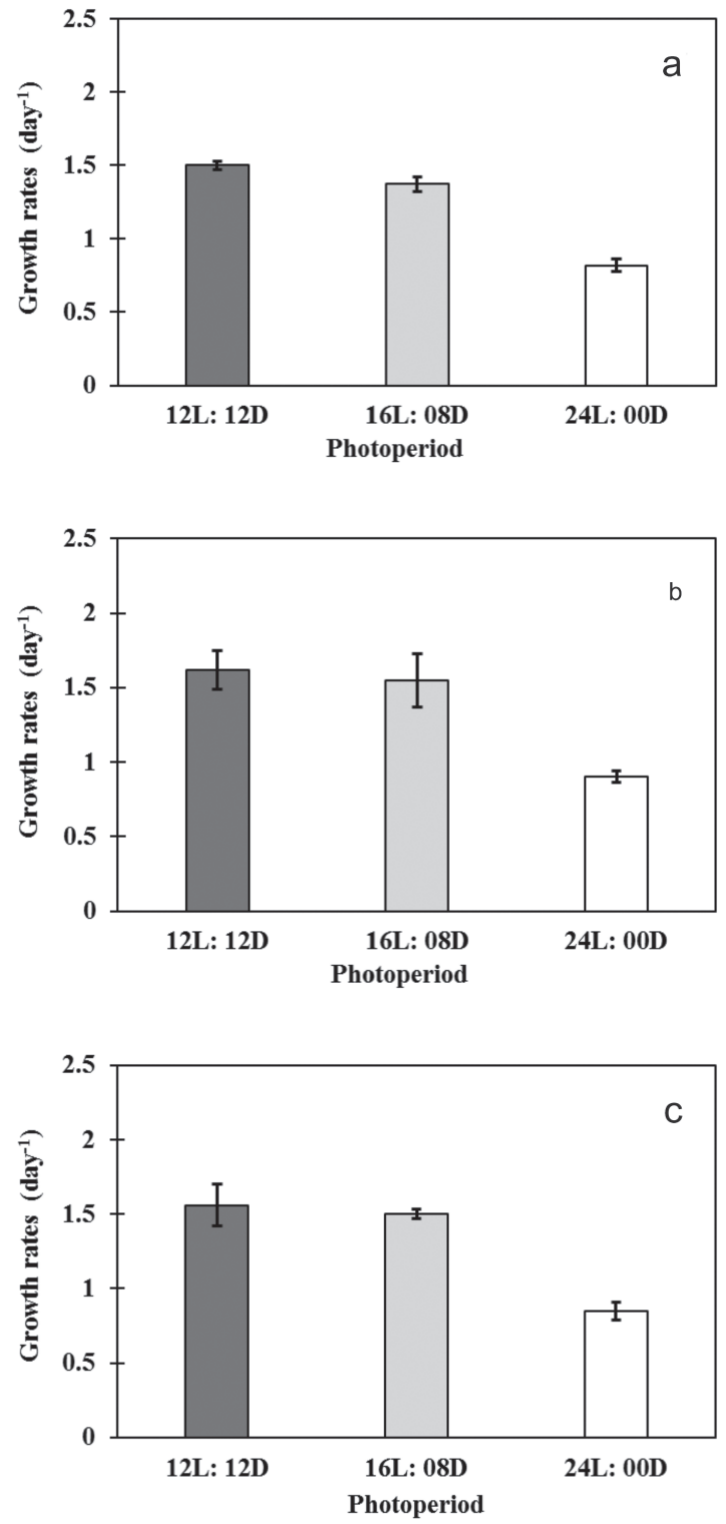

Fig. 3. Specific growth rate (mean \pm s.e) of Pseudanabaena catenata under $25^{\circ} \mathrm{C}$ (a), $15^{\circ} \mathrm{C}$ (b) and $4^{\circ} \mathrm{C}(\mathrm{c})$. 
hoc Duncan test, however, showed that the growth rates of $P$. catenata were not significantly different $(\mathrm{P}>0.05)$ between the experimental temperatures changes. Given the range of experimental temperatures used, this indicates that the study strain is psychrotolerant or psychrotrophic (sensu Morita 1975), as it is an organism from a cold environment that can adapt to culture temperatures $>15^{\circ} \mathrm{C}$. Measured growth rates of the strain were significantly higher $(\mathrm{P}<0.05)$ under 12L:12D than any other photoperiod.

The morphological plasticity of $P$. catenata was examined under various temperature and daylength combinations in order to identify any distinct or stable characteristics. We confirmed that the strain shows variation in cell dimensions and shape, as originally noted by Lauterborn (1915).

The morphological features of Pseudanabaena catenata observed in this study, in response to photoperiod and temperature variation are summarised in Table 2. The cell dimensions of the strain differed significantly between treatments. The cylindrical cell shape was consistent throughout, with cells mostly longer than wide or isodiametric, and with slight or distinct constrictions at the cross-walls (Lauterborn 1915). However, the cell length and width values obtained here were beyond the range (length $2-5 \mu \mathrm{m}$, width $1.4-2.2 \mu \mathrm{m}$ ) given by Lauterborn, (1915). For example, in our observations $\left(25^{\circ} \mathrm{C} ; 16 \mathrm{~L}: 08 \mathrm{D}\right)$, the cell length was frequently less than $2 \mu \mathrm{m}(1.91 \pm 0.26 \mu \mathrm{m})$, while the cell width was $3.05 \pm 0.13 \mu \mathrm{m}$ when cultured at $25^{\circ} \mathrm{C}$ (12L:12D). When cultured under 24L:00D and $25^{\circ} \mathrm{C}$ (agar) treatment, the strain showed the lowest cell width $(1.31 \pm 0.16 \mu \mathrm{m})$ of all treatments. An analogous conclusion was drawn by Zapomelova et al. (2008), who reported morphological variation occurring in two strains of cyanobacteria, Anabaena circinalis and A. crassa, when grown under various culture conditions.

The $15^{\circ} \mathrm{C}$ and $4^{\circ} \mathrm{C}$ treatments revealed similar outcomes (Table 2), with cell lengths differing significantly in different treatments. The longest cell length $(5.92 \pm 0.13 \mu \mathrm{m})$ was observed at $15^{\circ} \mathrm{C}$ under $12 \mathrm{~L}: 12 \mathrm{D}$ in BG-11 liquid media among all treatments. In agar media, the longest cell length was $5.15 \pm 0.18 \mu \mathrm{m}$ at $4^{\circ} \mathrm{C}$ under 12L:12D treatment as compared to other treatments. The shortest cell lengths in liquid $(1.59 \pm 0.33 \mu \mathrm{m})$ and in agar $(1.04 \pm 0.33 \mu \mathrm{m}) \mathrm{BG}-11$ media were obtained at $15^{\circ} \mathrm{C}(16 \mathrm{~L}: 08 \mathrm{D})$ and $4^{\circ} \mathrm{C}(24 \mathrm{~L}: 00 \mathrm{D})$, respectively. The greatest cell width $(3.24 \pm 0.06 \mu \mathrm{m})$ was observed at $4^{\circ} \mathrm{C}(12 \mathrm{~L}: 12 \mathrm{D})$. Generally, cyanobacteria grow best at average temperatures and possess morphological, physiological, and behavioural traits that confer advantages in strongly stratified environments (Winder and Sommer 2012). Previous studies have emphasised the importance of average temperature for active metabolic processes (Singh and Singh 2015). Thus, the integration of metabolic processes that occur in cyanobacterial cells may underlie the increases in the dimensions of vegetative cells we observed at $4^{\circ} \mathrm{C}$ and $15^{\circ} \mathrm{C}$. 
Table 2

Morphological characteristics of Pseudanabaena catenata apical cells obtained after culture under various temperature and photoperiod conditions ( $\mathrm{L}$ and $\mathrm{D}$ indicate light and dark hours, respectively).

\begin{tabular}{|c|c|c|c|c|c|}
\hline Treatments & $\begin{array}{l}\text { BG-11 } \\
\text { Media }\end{array}$ & $\begin{array}{l}\text { Cell length } \\
\quad(\mu \mathrm{m})\end{array}$ & $\begin{array}{l}\text { Cell width } \\
\qquad(\mu \mathrm{m})\end{array}$ & Cell shape & $\begin{array}{c}\text { Apical } \\
\text { cell } \\
\text { shape }\end{array}$ \\
\hline $25^{\circ} \mathrm{C} ; 16 \mathrm{~L}: 08 \mathrm{D}$ & Liquid & $1.91 \pm 0.26 \boldsymbol{E}$ & $1.9 \pm 0.07 \mathrm{~B}$ & $\begin{array}{l}\text { Cylindrical, longer } \\
\text { than wide }\end{array}$ & Rounded \\
\hline $25^{\circ} \mathrm{C} ; 16 \mathrm{~L}: 08 \mathrm{D}$ & Agar & $3.87 \pm 0.39 \boldsymbol{C}, \boldsymbol{D}$ & $1.65 \pm 0.16 \boldsymbol{A}, \boldsymbol{B}$ & $\begin{array}{l}\text { Cylindrical, some } \\
\text { are isodiametric }\end{array}$ & Rounded \\
\hline $25^{\circ} \mathrm{C} ; 12 \mathrm{~L}: 12 \mathrm{D}$ & Liquid & $3.12 \pm 0.25 \mathrm{~B}, \mathrm{C}$ & $3.05 \pm 0.13 \boldsymbol{A}, \boldsymbol{B}$ & $\begin{array}{l}\text { Cylindrical, mostly } \\
\text { isodiametric }\end{array}$ & Rounded \\
\hline $25^{\circ} \mathrm{C} ; 12 \mathrm{~L}: 12 \mathrm{D}$ & Agar & $4.06 \pm 0.35 C, D$ & $1.85 \pm 0.14 \boldsymbol{B}, \boldsymbol{C}$ & $\begin{array}{l}\text { Cylindrical, mostly } \\
\text { isodiametric }\end{array}$ & Rounded \\
\hline $25^{\circ} \mathrm{C} ; 24 \mathrm{~L}: 0 \mathrm{D}$ & Liquid & $2.62 \pm 0.19 \boldsymbol{E}$ & $1.79 \pm 0.09 A, B$ & $\begin{array}{l}\text { Cylindrical, mostly } \\
\text { longer than wide }\end{array}$ & Rounded \\
\hline $25^{\circ} \mathrm{C} ; 24 \mathrm{~L}: 0 \mathrm{D}$ & Agar & $3.87 \pm 0.21 \mathrm{D}, \mathrm{E}$ & $1.31 \pm 0.16 \mathrm{~A}$ & $\begin{array}{l}\text { Cylindrical mostly } \\
\text { isodiametric }\end{array}$ & Rounded \\
\hline $15^{\circ} \mathrm{C} ; 16 \mathrm{~L}: 08 \mathrm{D}$ & Liquid & $1.59 \pm 0.33 \boldsymbol{A}$ & $2.25 \pm 0.11 C, D$ & $\begin{array}{l}\text { Cylindrical, mostly } \\
\text { longer than wide }\end{array}$ & Rounded \\
\hline $15^{\circ} \mathrm{C} ; 16 \mathrm{~L}: 08 \mathrm{D}$ & Agar & $2.61 \pm 0.2 \mathrm{~B}$ & $1.94 \pm 0.12 \boldsymbol{B}, \boldsymbol{C}$ & $\begin{array}{l}\text { Cylindrical, mostly } \\
\text { isodiametric }\end{array}$ & Rounded \\
\hline $15^{\circ} \mathrm{C} ; 12 \mathrm{~L}: 12 \mathrm{D}$ & Liquid & $5.92 \pm 0.13 \boldsymbol{F}$ & $2.07 \pm 0.09 \boldsymbol{B}, \boldsymbol{C}$ & $\begin{array}{l}\text { Cylindrical, mostly } \\
\text { longer than wide }\end{array}$ & Rounded \\
\hline $15^{\circ} \mathrm{C} ; 12 \mathrm{~L}: 12 \mathrm{D}$ & Agar & $4.38 \pm 0.22 \boldsymbol{B}, \boldsymbol{C}$ & $2.08 \pm 0.12 C, D$ & $\begin{array}{l}\text { Cylindrical, mostly } \\
\text { isodiametric }\end{array}$ & Rounded \\
\hline $15^{\circ} \mathrm{C} ; 24 \mathrm{~L}: 0 \mathrm{D}$ & Liquid & $3.8 \pm 0.44 \boldsymbol{D}, \boldsymbol{E}$ & $2.48 \pm 0.9 \mathrm{D}$ & $\begin{array}{l}\text { Cylindrical, mostly } \\
\text { longer than wide }\end{array}$ & Rounded \\
\hline $15^{\circ} \mathrm{C} ; 24 \mathrm{~L}: 0 \mathrm{D}$ & Agar & $3.34 \pm 0.33 \boldsymbol{B}, \boldsymbol{C}$ & $2.33 \pm 0.14 \boldsymbol{D}, \boldsymbol{E}$ & $\begin{array}{l}\text { Cylindrical, mostly } \\
\text { isodiametric }\end{array}$ & Rounded \\
\hline $4^{\circ} \mathrm{C} ; 16 \mathrm{~L}: 08 \mathrm{D}$ & Liquid & $2.66 \pm 0.32 \boldsymbol{A}, \boldsymbol{B}$ & $1.81 \pm 0.13 \boldsymbol{A}, \boldsymbol{B}$ & $\begin{array}{l}\text { Cylindrical, mostly } \\
\text { longer than wide }\end{array}$ & Rounded \\
\hline $4^{\circ} \mathrm{C} ; 16 \mathrm{~L}: 08 \mathrm{D}$ & Agar & $2.84 \pm 0.38 \boldsymbol{B}$ & $1.96 \pm 0.14 \boldsymbol{B}, \boldsymbol{C}$ & $\begin{array}{l}\text { Cylindrical, mostly } \\
\text { isodiametric }\end{array}$ & Rounded \\
\hline $4^{\circ} \mathrm{C} ; 12 \mathrm{~L}: 12 \mathrm{D}$ & Liquid & $4.41 \pm 0.24 \boldsymbol{C}, \boldsymbol{D}$ & $3.24 \pm 0.06 \boldsymbol{E}$ & $\begin{array}{c}\text { Cylindrical, some } \\
\text { are } \\
\text { longer than wide }\end{array}$ & Rounded \\
\hline $4^{\circ} \mathrm{C} ; 12 \mathrm{~L}: 12 \mathrm{D}$ & Agar & $5.15 \pm 0.18 \boldsymbol{E}$ & $2.14 \pm 0.09 C, D$ & $\begin{array}{l}\text { Cylindrical, longer } \\
\text { than wide }\end{array}$ & Rounded \\
\hline $4^{\circ} \mathrm{C} ; 24 \mathrm{~L}: 0 \mathrm{D}$ & Liquid & $1.96 \pm 0.25 \boldsymbol{B}$ & $1.56 \pm 0.11 \mathrm{~A}$ & $\begin{array}{l}\text { Cylindrical, mostly } \\
\text { longer than wide }\end{array}$ & Rounded \\
\hline $4^{\circ} \mathrm{C} ; 24 \mathrm{~L}: 0 \mathrm{D}$ & Agar & $1.04 \pm 0.33 \mathrm{~A}$ & $2.7 \pm 0.13 E$ & $\begin{array}{l}\text { Cylindrical, mostly } \\
\text { isodiametric }\end{array}$ & Rounded \\
\hline
\end{tabular}

The values presented are the mean of three replicates and standard errors. Means were compared using the multiple range test of Duncan $(\alpha=0.05)$; groups with different letters are significantly different. 
Our findings agree with those of Zhang et al. (2015), who suggested that light exposure increase can cause considerable damage to the photosynthetic apparatus of cyanobacteria and subsequently lead to a sharp decrease in growth rate. Moreover, in the absence of light, the ability to grow will be reduced, and the cells will eventually die (Dehning and Tilzer 1989). In our study we observed a substantial effect of light on the morphological features of the strains. The longest and widest cells were recorded under a $12 \mathrm{~h}$ photoperiod. This might suggest that the day length naturally experienced in the tropics would provide the appropriate light-dark cycle for $P$. catenata to produce the longest and widest cells. Our data also showed that $P$. catenata strains cultivated in BG-11 agar media had lower cell length and width measures than those of the strains cultivated in liquid BG-11 media, although in some cases it is likely that there were hormogonia between the smaller cells.

An important finding of our study, the stability of apical cell shape ( $c f$. Lauterborn 1915) under different experimental conditions, also contributes to the identification confirmation of this strain. Thus, the stability of apical cell shape under the various imposed conditions appears to provide a reliable criterion for the identification of $P$. catenata. The shape of the apical cell and the presence of polar aerotopes are very important elements in the identification of members of the genus Pseudanabaena at the species level (Komárek and Anagnostidis 2005), highlighting the important contributions of both traditional taxonomic and newer molecular approaches for species identification in this group of cyanobacteria.

TEM analysis. - TEM analysis (Fig. 4) clearly showed the presence of cell wall constrictions and a uniseriate row of connected cells (Fig. 4a, c). Cells have five peripheral thylakoids parietally arranged in the peripheral cytoplasm and concentrically arranged around the long axis of the trichome (Fig. 4a, b). Lipid droplets, polyphosphate, and phycocyanin granules were present (Fig. 4a, c) in the nucleoplasm. TEM analysis confirms the description of $P$. catenata ultrastructure as previously given by Komárek and Anagnostidis (2005).

\section{Molecular characterisation}

In addition to morphological characterisation in culture, we also applied molecular sequencing for confirmation of identification. Pseudanabaena catenata strain USMAC16 was characterized by $16 \mathrm{~S}$ rRNA gene analysis, and showed pair-wise sequence identity in the range of 100 to $94 \%$ with 52 strains of cyanobacteria available in the GenBank. The strain USMAC16 showed $100 \%$ pairwise sequence identity with $P$. catenata SAG 1464-1 (accession no. KM020005.1) originally isolated in Germany, that satisfies the molecular limits for species identification indicated by Stackebrandt and Ebers 


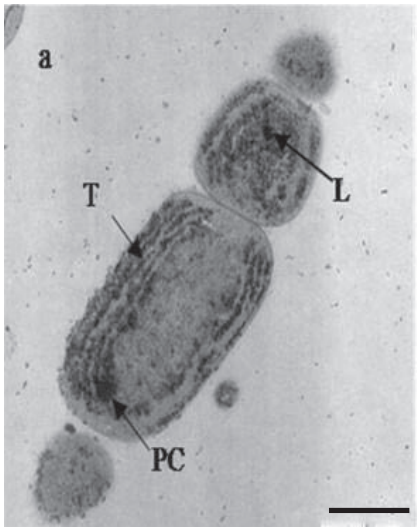

b

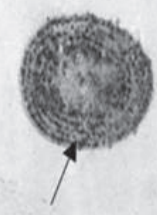

T c

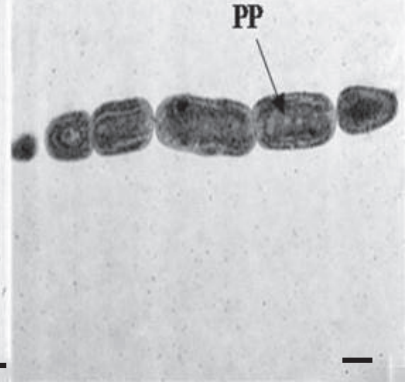

Fig. 4. Ultrastructure of Pseudanabaena catenata. Thylakoids are marked with T, phycocyanin granules are marked with PC, lipid droplets are marked as L and polyphosphate granules with PP. Scale bar $1 \mu \mathrm{m}$.

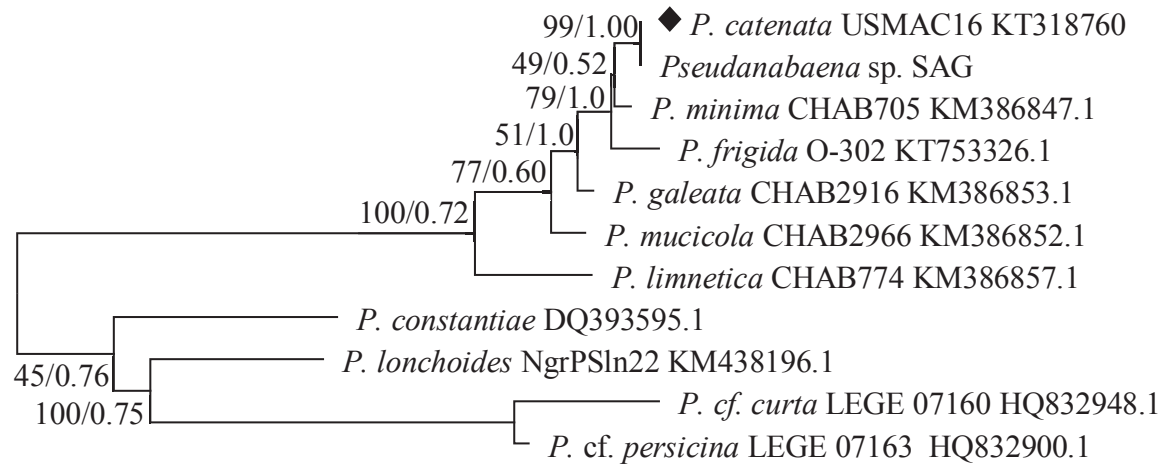

$\overline{0.02}$

Fig. 5. Maximum Likelihood (ML) tree showing phylogenetic relationships between Pseudanabaena catenata USMAC16 based on 16S rRNA gene sequences with other 10 species of Pseudanabaena with 2078 bp nucleotides. New isolated strains in this study are shown with filled diamond. Numbers associated with nodes are Maximum likelihood bootstrapped percentages /Bayesian posterior probability.

(2006). Unfortunately, no morphological data are available in the published literature to compare these two strains. The strain also showed $99 \%$ similarity with Pseudanabaena sp. 0830-3 (GenBank accession no. AB936777.1) isolated from Lake Hachiro-ko, Japan (Okano et al. 2015). The phylogenetic tree based on 16S rRNA sequences shows that the current strain and P. catenata SAG 1464-1 are in the same clade, supported by high bootstrap value and Bayesian posterior 


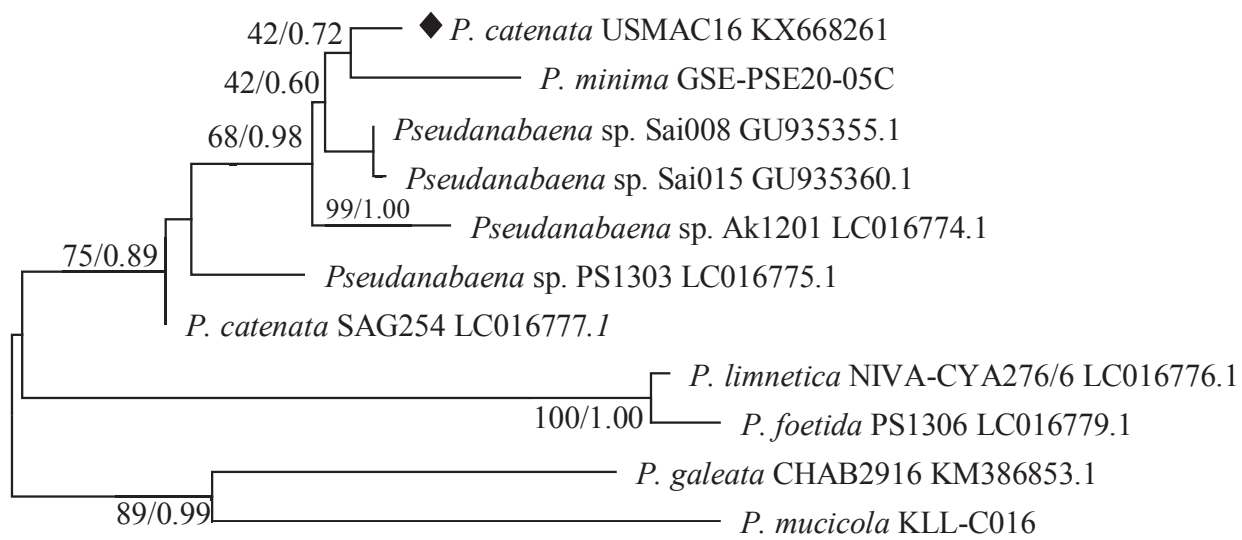

$\overline{0.02}$

Fig. 6. Maximum Likelihood (ML) tree showing phylogenetic relationships between Pseudanabaena catenata USMAC16 based on ITS sequences with other 10 strains of Pseudanabaena. New isolated strains in this study are shown with filled diamond. Numbers associated with nodes are Maximum likelihood bootstrapped percentages /Bayesian posterior probability.

probability, of $99 \%$ and 1.0 respectively (Fig. 5). The analysis of the $16 \mathrm{~S}-23 \mathrm{~S}$ ITS region showed that the strain shared $98 \%$ similarity with Pseudanabaena sp. Ak1201 (accession no. LC016774.1) and 97\% similarity with P. catenata SAG254 (accession no. LC016777.1) (Japan). However, hypervariability of the ITS region between geographically remote populations within a single species could explain the $3 \%$ divergence in the ITS region of the current strain with $P$. catenata SAG254 which is presented in tree based on ITS region (Fig. 6). However, it shares sister clade with P. minima GSE-PSE20-05C but it is not supported by bootstrap value and Bayesian posterior probability.

\section{Conclusion}

Polyphasic characterisation of a Pseudanabaena isolate obtained from High Arctic Svalbard provides new insight in taxonomic studies and contributes to the taxonomic revision of Pseudanabaena. Our data indicate that higher temperature and longer photoperiod lead to reduction in the width and length of individual cells. Even though light is required for cyanobacteria to carry out photosynthesis, longer light exposure was not associated with the maximum cell length and width values observed. Our data indicate that light-dark cycle of 12 hours light and 12 hours darkness allows $P$. catenata to produce the longest and widest cells. Consistent apical cell shape under the various culture conditions applied appears to provide a reliable criterion for the identification of this species. 
Acknowledgements. - This study was funded and supported by Flagship grant (304/PBIOLOGI/650723/P131) from the Ministry of Science, Technology and Innovation, Malaysia. We would like to thank Mohammed Basri Eshak for his assistance in statistical analysis.

\section{References}

Acinas S.G., HaverkamP T.H.A., Huisman J. and Stal L.J. 2009. Phenotypic and genetic diversification of Pseudanabaena spp. (cyanobacteria). ISME Journal 3: 31-46.

ANAGNOSTIDIS K. and KOMÁREK J. 1988. Modern approach to the classification system of cyanophytes. 5. Oscillatoriales. Archiv für Hydrobiologie 80: 327-472.

ANDERSEN R.A. 2005. Algal Culturing Techniques. Elsevier Academic Press: 92-94.

BOYER S.L., FLECHTNER V.R. and JOHANSEN J.R. 2001. Is the 16S-23S rRNA internal transcribed spacer region a good tool for use in molecular systematics and population genetics? A case study in cyanobacteria. Molecular Biology and Evolution 18: 1057-1069.

BORNET É. and Flahault C. 1886. Revision des Nostocacées hétérocystées contenues dans les principaux herbiers de France (quatrième et dernier fragment). Annales des Sciences Naturelles, Botanique, Septième Série 7: 177-262.

Castenholz R.W. 2001. Phylum BX. Cyanobacteria. Oxygenic Photosynthetic Bacteria. In: D.R. Boone, R.W. Castenholz and G.M. Garrity (eds), Bergey's Manual of Systematic Bacteriology. Volume 1: The Archaea and the Deeply Branching and Phototropic Bacteria. SpringerVerlag, New York: 413-439.

DEHNING I. and TILZER M.M. 1989. Survival of Scenedesmus acuminatus (Chlorophyceae) in darkness. Journal of Phycology 25: 509-515.

GeITLER L. 1932. Cyanophyceae. In: Rabenhorst L. (ed.), Kryptogamen Flora von Deutschland, Osterreich und der Schweiz 14. Akademische Verlagsgesellschaft, Leipzig: 130-159.

Gomont M. 1892. Monographie des Oscillariées (Nostocacées Homocystées). Deuxième partie. Lyngbyées. Annales des Sciences Naturelles, Botanique, Série 7 16: 91-264.

GUPTA S. and AGRAWAL S.C. 2006. Survival of blue-green and green algae under stress conditions. Folia Microbiologica 51: 121-128.

Gugger M., Lyra C., SuOminen I., TsitKo I., Humbert J.F., SAlKinOJA-SAlOnen M.S. and SIVONEN K. 2002. Cellular fatty acids as chemotaxonomic markers of the genera Anabaena, Aphanizomenon, Microcystis, Nostoc and Planktothrix (cyanobacteria). International Journal of Systematic and Evolutionary Microbiology 52: 1007-1015.

KaŠTOVSKÁ K., Elster J., STiBAL M. and ŠANTRŮČKOVÁ H. 2005. Microbial Assemblages in Soil Microbial Succession After Glacial Retreat in Svalbard (High Arctic). Microbial Ecology 50: 396-407.

KLING H. and WATSON S. 2003. A new planktic species of Pseudanabaena (cyanoprokaryota, Oscillatoriales) from North American large lakes. Hydrobiologia 502: 383-388.

KomÁReK J. 2003. Problem of the taxonomic category "species" in cyanobacteria. Algological Studies 109: 281-297.

KoMÁREK J. 2006. Cyanobacterial taxonomy: current problems and prospects for the integration of traditional and molecular approaches. Algae 21: 349-375.

KoMÁREK J. and ANAGNOSTIDIS K. 1986. Modern approach to the classification system of cyanophytes. 2. Chroococcales. Archiv für Hydrobiologie, Supplement 73: 157-226.

KOMÁREK J. and ANAGNOSTIDIS K. 1989. Modern approach to the classification system of Cyanophytes 4 - Nostocales. Archiv für Hydrobiologie, Supplement 82: 247-345.

KomÁREK J. and ANAGNOSTIDIS K. 2005. Süsswasserflora von Mitteleuropa. Cyanoprokaryota: 2.Teil/2nd Part: Oscillatoriales. Vol. 19. Elsevier, Verlag, München: 86 pp. 
KomÁrek J., KAstovsky J., MAReS J. and Johansen R.J. 2014. Taxonomic classification of cyanoprokaryotes (cyanobacterial genera), using a polyphasic approach. Preslia 86: 295-335.

KVÍDEROVÁ J. and LUKAVSKÝ J. 2001. A new unit for crossed gradients of temperature and light. In: J. Elster, J. Seckbach, W.F. Vincent and O. Lhotský (eds), Algae and extreme environments. Nova Hedwigia, Beihefte, Beih, Stuttgart 123: 541-550.

LAUTERBORN R. 1915. Die sapropelische Lebewelt. Ein Beitrag zur Biologie des Faulschlammes natürlicher Gewässer. Verhandlungen des Naturhistorisch Medizinischen Vereins zu Heidelberg. Neue Folge 13: 395-481.

Lyra C., Suomalainen S., Gugger M., Vezie C., Sundman P., Paulin L. and Sivonen K. 2001. Molecular characterization of planktic cyanobacteria of Anabaena, Aphanizomenon, Microcystis and Planktothrix genera. International Journal of Systematic and Evolutionary Microbiology 51: 513-526.

MORITA R.Y. 1975. Psychrophilic bacteria. Bacteriological Reviews 39: 144-167.

NALEWAJKO C. and MURPHY T. 2001. Effect of temperature and availability of nitrogen and phosphorous on abundance of Anabaena and Microcystis in Lake Biwa, Japan: an experimental approach. Limnology 2: 45-48.

Okano K., Suzuki E., Ohta S., MiYata N., TANi Y. and OZAKI Y. 2015. Seasonal changes in cyanotoxin and toxic cyanobacteria in lake Hachiro. Journal of Japan Society on Water Environment 38: 23-30.

RipPKa R., Deruelles J., WATERbury J. B., Herdman M. and Stanier R.Y. 1979. Generic assignments, strain histories and properties of pure cultures of cyanobacteria. Journal of General Microbiology 111: 1-61.

RONQUIST F. and HUELSENBECK J.P. 2003. MRBAYES 3-Bayesian phylogenetic inference under mixed models. Bioinformatics 19: 1572-1574.

SingH S.P and SingH P. 2015. Effect of temperature and light on the growth of algae species: A review. Renewable and Sustainable Energy Reviews 50: 431-444.

STACKEBRANDT E. and EBERS J. 2006. Taxonomic parameters revisited: Tarnished gold standards. Microbiology Today 33: 152-155.

SZAFER W. 1910. Zur Kenntnis der Schwefelflora in der Umgebung von Lemberg. Bulletin International de l'Académie des Sciences de Cracovie, Classe des Sciences Mathématiques et Naturelles, Série B: 161-167.

Tamura K., Stecher G., Peterson D., Filipski A. and Kumar S. 2013. MEGA6, Molecular Evolutionary Genetics Analysis version 6.0. Molecular Biology and Evolution 30: 2725-2729.

WINDER M. and SOMMER U. 2012. Phytoplankton response to a changing climate. Hydrobiologia 698: 5-16.

Yu G., Zhu M., Chen Y., PAN Q., ChaI W. and Li R. 2015. Polyphasic characterization of four species of Pseudanabaena (Oscillatoriales, Cyanobacteria) from China and insights into polyphyletic divergence within the Pseudanabaena genus. Phytotaxa 192: 1-12.

Zapomelova E., Hisem D., Rehakova K., HrouzeK P., Jezberova J., Komarkova J., KoreluSOVA J. and ZNACHOR P. 2008. Experimental comparison of phenotypic plasticity and growth demands of two strains from the Anabaena circinalis/A. crassa complex (cyanobacteria). Journal of Plankton Research 30: 1257-1269.

Zhang D., Dechatiwongse P., Del Rio-Chanona E.A., Maitland G.C., Hellgardt K. and VASSILIADIS V.S. 2015. Modelling of light and temperature influences on cyanobacterial growth and biohydrogen production. Algal Research 9: 263-274. 